\title{
Lanthanides in Soils: X-Ray Determination, Spread in Background and Contaminated Soils in Russia
}

\author{
Yu. N. Vodyanitskii and A. T. Savichev \\ Department of Soil Science, Moscow State University; Geological Institute, RAS \\ Russia
}

\section{Introduction}

Rare elements in soils are poorly studied because of the problems in their determination (Perelomov, 2007). The rare earth elements include lanthanum (La) and its group of 14 elements. They are subdivided into two subgroups: the light cerium group of elements with atomic masses lower than $153(\mathrm{La}, \mathrm{Ce}, \mathrm{Pr}, \mathrm{Nd}, \mathrm{Sm}$, and $\mathrm{Eu}$ ) and the heavy yttrium group of elements with atomic masses higher than 153 (Y, Gd, Tb, Dy, Ho, Er, Tm, Yb, and Lu, with an exception for Y) (Tyler, 2004a).

The interest in rare earth elements in soils increased in the 1990s, when they found wide use as microfertilizers for some crops in China, which increased the yield and quality of grain (Evans, 1990; Wu, Guo, 1995; Zhu et al., 1995). Rare earth elements are accumulated in soils due to fertilization. Groundwater and plants can be contaminated in the regions enriched with soluble rare earth metals and in the soils fertilized with sewage sludge for long time (Zhu et al., 1995). Data are available on the strong contamination of coastal sediments with lanthanidecontaining industrial waste (Savichev, Vodyanitskii, 2009). Neither positive nor negative geochemical anomalies of natural or technogenic rare earth metals have been revealed in Russia until now. The contribution of rare earth metals to the main soilforming processes is not clear.

The content of lanthanides was compared to their soil clarkes. Questions arise in this connection. The yttrium clarke value is $40 \mathrm{mg} / \mathrm{kg}$ (Bowen, 1979). We shall take this value, although we consider it to be too high.

We analyzed the clarkes of the rare earth elements (La and Ce) according to the book by Kabata-Pendias and Pendias (1985), in which they were borrowed from three sources. Let us judge the validity of the published La and Ce clarkes according to the Ce : La ratio in the world soils. The clarkes proposed by Lawl et al. (according to Kabata-Pendias and Pendias, 1985 ) are the least probable of all, as they give a too low ratio of $\mathrm{Ce}: \mathrm{La}=29.5: 29.5=1$. On average, the Ce : La ratio $=2.2$ for the soils in Japan; it is equal to 2.0, for the soils in China; and to 1.8, for the soils in Bryansk oblast of Russia. According to our data, this ratio is equal on average to 1.5 in the soils of the Kolyma depression, as well as in the alluvial fine earth of the small rivers and the Kama River in Perm (Savichev, Vodaynitskii, 2009). Bowen (1979) 
also suggests too low a ratio $(\mathrm{Ce}: \mathrm{La}=50: 60=1.2)$. This ratio reaches a probable value only for the clarkes proposed by Yuri and Baikon: $\mathrm{Ce}: \mathrm{La}=49: 34=1.4$. These values of the lanthanum $(34 \mathrm{mg} / \mathrm{kg})$ and cerium $(49 \mathrm{mg} / \mathrm{kg})$ clarkes we shall use further. In sedimentary rocks, the clarkes of La and other lanthanides depend on the particle size distribution, because these elements are accumulated in the clay fraction $<2 \mu \mathrm{m}$. As a result, their content is higher in argillites and clays $(56 \mathrm{mg} / \mathrm{kg}$ ) and lower in sandstones and carbonates (19 and $8 \mathrm{mg} / \mathrm{kg}$, respectively) (Ivanov, 1997).

The clarkes of other studied lanthanides in the earth's crust are as follows (mg/kg): $\operatorname{Pr}$, 9; $\mathrm{Nd}, 40$; and Sm, 7 (Greenwood, Ernshaw, 1997). In soils, they are lower (mg/kg): Pr, 7.6; Nd, 19; and Sm, 4.5 (Dyatlova et al., 1988). The values of the soil clarkes are used to detect positive and negative geochemical anomalies. Unfortunately, there are no clear criterions for such identification. As a first approximation, we use the condition that a soil belongs to the territory of a strong positive anomaly at the double excess of the clarke $\left(X_{s}: X_{c l}>2\right)$.

\section{Methods}

The recent progress in the study of rare earth elements was related to the use of the expensive method of inductively coupled plasma mass spectroscopy (ICP MS) (Kashulina et al., 2007; Perelomov, 2007).

The expensive method of neutron-activation analysis using a nuclear reactor with the use of a gamma spectrometer allows determining the different dispersed elements in soils - Hf, La, $\mathrm{Ce}, \mathrm{Sm}, \mathrm{Eu}, \mathrm{Yb}, \mathrm{Lu}, \mathrm{Th}$, and $\mathrm{U}$ - even at low concentrations (Inisheva et al., 2007; Nikonov et al., 1999). However, the identification of $\mathrm{Pr}$ and $\mathrm{Nd}$ by this method is complicated because of the short lifetime of these elements (Ivanov et al., 1986).

$\mathrm{X}$-ray fluorescence is the simplest and least expensive method for studying the heavy metals in soils (Savichev, Sorokin, 2000). The contents of rare ( $\mathrm{Zr}$ and $\mathrm{Nb}$ ) and rare earth (Y) elements are determined by this method. However, when a Mo, Rh, or Ag anode of the Xray tube and a common voltage of $35-40 \mathrm{kV}$ are used, other rare earth elements can be identified only from the $L$-lines. Their intensities are lower than those of the $K$-lines by several times, and the weak $L$-lines are overlapped by the strong $K$-lines of macroelements. Niobium with $Z=41$ is the last element reliably identified by conventional $X$-ray fluorescence analysis, because the scattered lines of the anode material are located father in the energy spectrum, and the elements with atomic numbers higher than that of the anode material are not excited.

A radically different situation is observed when the X-ray radiometric modification of the energy dispersive X-ray fluorescence method is used, in which the sample is excited by a highenergy radioisotope source ${ }^{241} \mathrm{Am}$ rather than by the $\mathrm{X}$-ray tube radiation. This source is the most suitable for this purpose. An advantage of this method is that the $K$-lines of the heavy metals are actively excited in this case and are not overlapped by the lines of macroelements. Other advantages are the low background radiation compared to X-ray tubes, the high stability, and the small size.

The aim of this part of work is to elaborate methods of X-ray radiometric determination of the first lanthanides (lanthanum and cerium) and barium and to determine the content of these elements in some soils. 
Calibration diagrams were compiled with the use of standard samples of rocks and soils. There were 18 samples of magmatic rocks, including ultramafic (UMR), mafic (MR), acidic (AR), and alkaline (ALR) series (Khitrov, 1984). Thus, standard samples of gabbro (SGD-1A), granites (SG-1A and SG-2), trappean rock (ST-1), siltstone (SA-1), and others were analyzed. Standard soil samples included Kursk chernozem (SP-1), Moscow soddy-podzolic soil (SP2), Caspian light chestnut soil (SP-3), krasnozem (SKR), and calcareous serozem (SSK). Detailed data on these standard samples are given in (Arnautov, 1987). It is important that the intensities of characteristic lines of studied elements do not depend on the mineralogical and textural specificity of the samples.

Conventional X-ray fluorescence and X-ray radiometric approaches were compared with the use of two energy dispersive X-ray fluorescence analyzers EX-6500 (Baird) and Tefa-6111 (Ortec). An EX-6500 analyzer had the following parameters: voltage $35 \mathrm{kV}$, current $400 \mu \mathrm{A}$, Rh-anode, Rh-filter, and storage time $400 \mathrm{~s}$. The regime of a Tefa-6111 (Ortec) analyzer was as follows: voltage $30 \mathrm{kV}$, current $200 \mu \mathrm{A}$, Mo-anode, Mo-filter, and storage time $400 \mathrm{~s}$. Samples were prepared for traditional working regimes via tableting. The main requirement for tablets was that they should produce saturated emission spectra, which was achieved upon their mass of about $3 \mathrm{~g}$.

Instead of the traditional sample excitation by emanation from an X-ray tube, excitation by isotope source ${ }^{241} \mathrm{Am}$ with energy of $59 \mathrm{keV}$ and activity of $3.7 \cdot 10^{10} \mathrm{~s}^{-1}$ was used for a Tefa6111 analyzer. Preparation of the samples for the X-ray radiometric method was simple: powdered samples were placed in polyethylene dishes with 5- $\mu$ m-thick Mylar bottoms. The mass of the powdered samples was about $8 \mathrm{~g}$ (exact weight of the sample is not required for this analysis). For an EX-6500 analyzer, the radioisotopic excitation was not efficient, because hard quanta of $K$-lines of the investigated elements penetrated through the detector and were only slightly slowed down by it.

Spectra of microelements in a standard sample of granite (SG-1A) obtained on an EX-6500 analyzer are given in Fig. 1. Upon a traditional X-ray fluorescence analysis, niobium is the last determined element. Elements with greater numbers are not excited, and scattered lines of the anode material are only situated farther on the energy spectrum.

The spectra from granite (SG-1A) and chernozem (SP-1) upon their excitation by the radioisotope source are shown in Fig. 2. The needed $\mathrm{K}$-lines of $\mathrm{Cs}, \mathrm{Ba}, \mathrm{La}, \mathrm{Ce}$, and $\mathrm{Nd}$ are clearly seen. A comparison of the spectra shown in Figs. 1 and 2 indicated that the X-ray radiometric approach is useful for determining $\mathrm{Cs}-\mathrm{Nd}$ series. Cesium is reliably determined, when its content exceeds $10 \mathrm{mg} / \mathrm{kg}$, which is typical of the soils enriched by natural or anthropogenic Cs. Upon the X-ray radiometric excitement, $K$-lines of neodymium are overlapped by $K$-line ( $\beta$ components) of barium and are well seen in the samples with the low Ba content (in particular, in granites). In the soils with the $\mathrm{Ba}$ content above $400 \mathrm{mg} / \mathrm{kg}$, the determination of neodymium is difficult. Thus, only Ba, La, and $\mathrm{Ce}$ are reliably determined in the soils.

We studied metrological characteristics of the new approach using a set of 30 standard samples of soils and rocks. The limit of element determination was $4 \mathrm{mg} / \mathrm{kg}$ at storage time of $800 \mathrm{~s}$. 


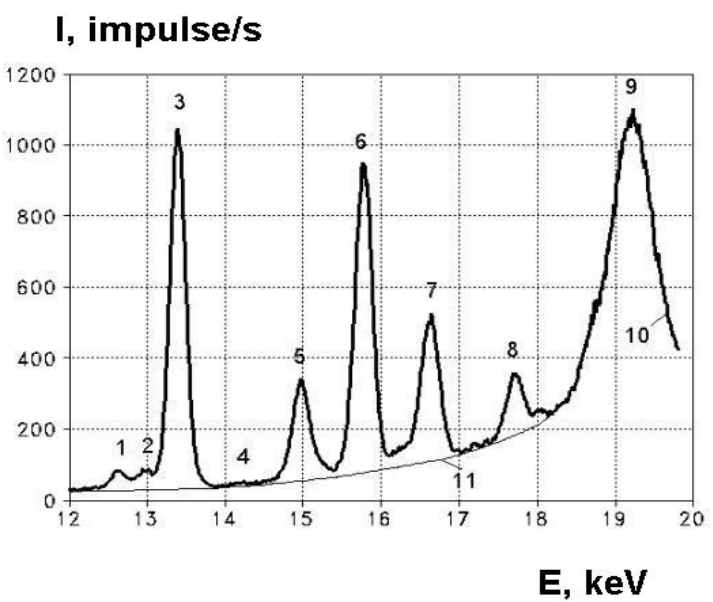

Fig. 1. Part of the SSC SG-1A spectrum from $\mathrm{Pb} L_{\beta}$ to $\mathrm{Zr} K_{\beta}$ (EX-6500 analyzer, X-ray fluorescence method). Position of characteristic lines on the curve: (1) $\mathrm{Pb} L_{\beta^{\prime}}$ (2) Th $L_{\alpha^{\prime}}$ (3) $\mathrm{Rb}$ $K_{\alpha^{\prime}}$ (4) $\mathrm{Sr} K_{\alpha^{\prime}}(5) \mathrm{Y} K_{\alpha}+\mathrm{Rb} \mathrm{K}_{\beta^{\prime}}(6) \mathrm{Zr} K_{\alpha^{\prime}}$ (7) $\mathrm{Nb} K_{\alpha}+\mathrm{Y} K_{\beta^{\prime}}$ (8) Zr $K_{\beta^{\prime}}$ (9) incoherent scattering Rh $K_{\alpha}$ (material of anode), (10) distribution given by multichannel analyzer, (11) approximation of background radiation.
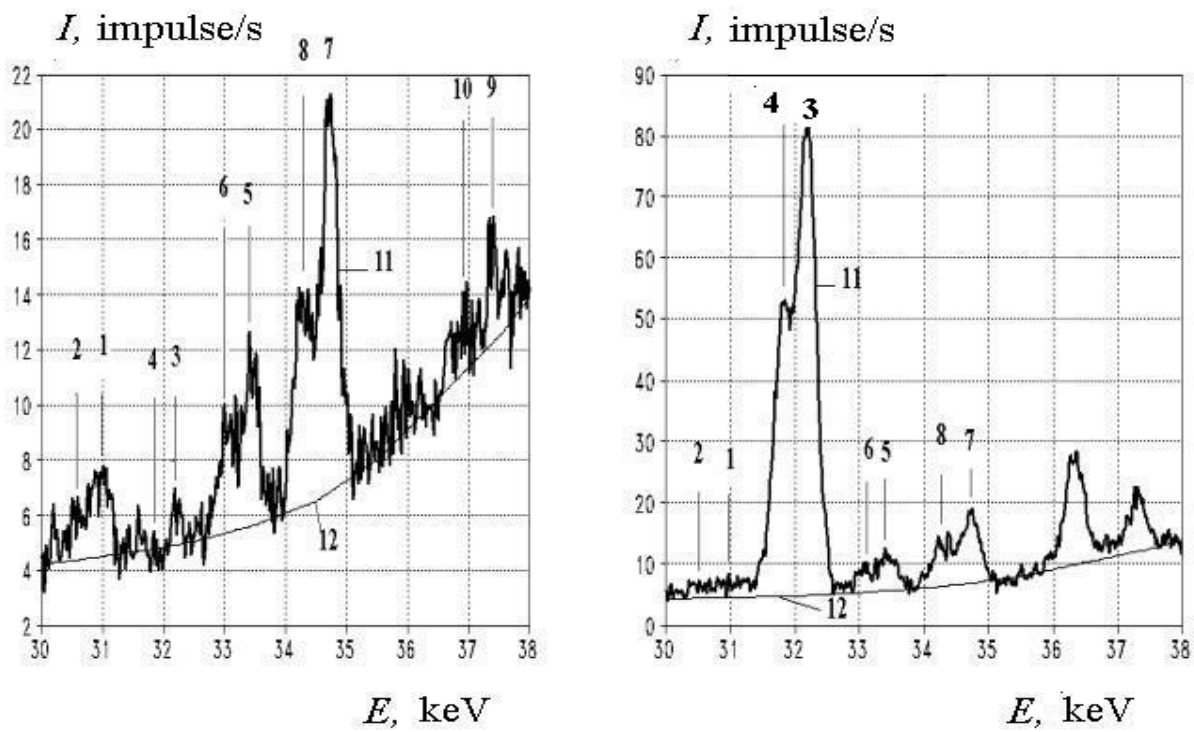

Fig. 2. Parts of the SSC SG-1A spectrum of granite (left) and SSC SP-1 spectrum of chernozem (right) from $\mathrm{Cs} K_{\alpha}$ to $\mathrm{Nd} K_{\alpha}$ (TEFA-6111 analyzer; X-ray radiometric method). Position of characteristic lines: (1) Cs $K_{\mathrm{a} 1^{\prime}}$ (2) Cs $K_{\mathrm{a} 2^{\prime}}$ (3) Ba $K_{\mathrm{a} 1^{\prime}}$ (4) Ba $K_{\mathrm{a} 2^{\prime}}$ (5) La $K_{\mathrm{a} 1^{\prime}}$ (6) La $K_{\mathrm{a} 2^{\prime}}$ (7) Ce $K_{\mathrm{a} 1^{\prime}}(8) \mathrm{Ce} K_{\mathrm{a} 2^{\prime}}(9) \mathrm{Nd} K_{\mathrm{a} 1^{\prime}}(10) \mathrm{Nd} K_{\mathrm{a} 2^{\prime}}(11)$ distribution given by multichannel analyzer, and (12) approximation of background radiation. 
The error of the new analytic approach should be known. Absolute $\Delta C$ or relative $\Delta C / C$ deviation from the mean is usually used for error assessments. The advantage of the relative deviation is that it gives different estimates of the error upon high and low concentrations of determined elements. A multiplier $1 / C$ is a statistical weight of an absolute error. However, relative deviation also depends on element concentrations changing within a wide range of values. The requirements of the Scientific Council on analytic methods (Berenshtein et al., 1979) are met upon the specification of element concentrations into small ranges and with the determination of the relative deviation in each range. The lower an element concentration, the higher the relative deviation. In order to obtain a more consistent estimate of the error working in a wide range of element concentrations, a different statistical weight should be chosen. Multiplier $1 / C^{1 / 2}$ is the best statistical weight. The error measure equal to $\Delta C / C^{1 / 2}$ (K-factor) should be used (Savichev, Fogel'son, 1987). The $K$-factor makes it possible to describe the error within a wide range of concentrations without its subdivision into smaller ranges. In addition, the structure of $K$-factor agrees with the fact that the detection of $\mathrm{X}$-ray roentgen spectra is based on the counting of impulses, which is a Poisson process, for which the variance correlates with the square root of the mean.

The accuracy of determination corresponds to the third category (according to the requirements of the Scientific Council on analytic methods) at the lower limit of determinable concentrations $(8 \mathrm{mg} / \mathrm{kg})$, to the second category at concentrations about 100 $\mathrm{mg} / \mathrm{kg}$, and to the first category at the concentrations about $500 \mathrm{mg} / \mathrm{kg}$. Metrological data on the $\mathrm{Ba}, \mathrm{La}$ and Ce elements are given in Table 1.

\begin{tabular}{|c|c|c|}
\hline Element & Range of measured concentrations, $\mathrm{mg} / \mathrm{kg}$ & K-factor \\
\hline $\mathrm{Ba}$ & $10-2000$ & 1.28 \\
\hline $\mathrm{La}$ & $10-150$ & 1.02 \\
\hline $\mathrm{Ce}$ & $10-250$ & 1.07 \\
\hline
\end{tabular}

Table 1. Metrological data on the X-ray radiometric analysis of microelements in soils.

The detection of $\mathrm{Pr}, \mathrm{Nd}$, and $\mathrm{Sm}$ faces some problems. Their determination is complicated by the fact that the $K_{\alpha 1,2}$ lines of Pr and $\mathrm{Nd}$ are overlapped by the Ba $K_{\beta 1,2}$ and La $K_{\beta 1}$ lines. The determination of Pr is also complicated by its low content in soils. The problems of the Sm identification are the same as for Pr and Nd.

The general view of the spectra for the region of elements from Ba to Sm is shown in Fig. 3A for the SGD-1A gabbro-essexite reference standard. An especially strong overlapping is observed in the energy region of 35-38 keV, which appreciably deforms the true intensities of the Pr and Nd spectral lines. A detailed view of this spectral region is shown in Fig. 3B.

The main objective in the determination of the true line intensities of $\mathrm{Pr}$ and $\mathrm{Nd}$ is to correctly simulate the disturbing $\mathrm{Ba} K_{\beta 1,2}$ and $\mathrm{La} K_{\beta 1}$ lines. For this purpose, an adequate model should be selected for the spectral line contour. There are two main approaches. The first is an experimental approach in which the line contours of pure elements are used as model spectral lines. The second is an analytical approach in which the model line contour is specified by a mathematical function (in our case, a Gaussian curve). However, both approaches presume the intensity ratio of the $a$ and $\beta$ components to be stable. The 
experimental ratio between the $\mathrm{Ba} K_{\alpha 1}$ and $\mathrm{Ba} K_{\beta 1}$ line intensities is 5:1. However, in the spectra of real samples, this ratio was found to be slightly lower (by 20\%) and varied (by about $10 \%$ ) among the samples; i.e., this ratio is subjected to matrix effects, which should be taken into consideration in the determination of the true intensities of the Pr and $\mathrm{Nd}$ lines. Therefore, the Gaussian model was used as a model of the spectral line contours, and the ratio between the $\alpha$ and $\beta$ components was selected for each sample on the basis of the best agreement between the top segment of the $\mathrm{Ba} K_{\beta 1}$ line and the experimental spectrum, as is shown in Fig. 3B. An adjustment of the model contour on the energy scale was also performed: a parallel shift within an arbitrary number of the analyzer channels (for the energy resolution, $10 \mathrm{eV} /$ channel).
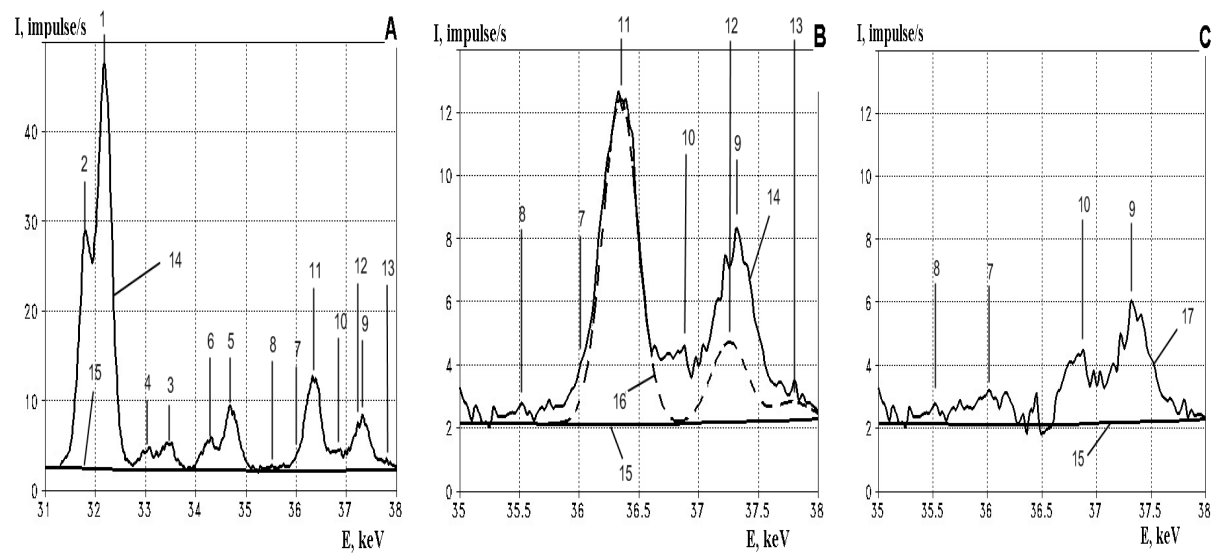

Fig. 3. Spectral segment corresponding to the $K$-lines of $\mathrm{Ba}, \mathrm{La}, \mathrm{Ce}, \mathrm{Pr}$, and $\mathrm{Nd}$ for the SGD1A (gabbro-essexite) reference standard: (A) general spectrum view; (B) detailed interpretation of the spectrum for Pr and $\mathrm{Nd}$ with the simulation of the $K_{\beta}$ components of the $\mathrm{Ba}$ and La lines; $(\mathrm{C})$ the spectrum after the subtraction of the $K_{\beta}$ components. The spectral lines: (1) Ba $K_{\mathrm{\alpha} 1^{\prime}}$ (2) Ba $K_{\mathrm{\alpha} 2^{\prime}}(3) \mathrm{La} K_{\mathrm{\alpha} 1^{\prime}}$ (4) La $K_{\mathrm{\alpha} 2^{\prime}}$ (5) Ce $K_{\mathrm{\alpha} 1^{\prime}} ;(6) \mathrm{Ce} K_{\mathrm{\alpha} 2^{\prime}}$ (7) Pr $K_{\mathrm{\alpha} 1^{\prime}}(8)$ $\operatorname{Pr} K_{\mathrm{\alpha} 2} ;(9) \mathrm{Nd} K_{\mathrm{\alpha} 1} ;(10) \mathrm{Nd} K_{\mathrm{\alpha} 2} ;(11) \mathrm{Ba} K_{\beta 1} ;(12) \mathrm{Ba} K_{\beta 2} ;(13) \mathrm{La} K_{\beta 1}$. (14) the original spectrum obtained by the energy dispersive analyzer; (15) approximation of the background radiation; (16) simulation of the $K_{\beta}$ components of the Ba and La lines; (17) true spectrum after the subtraction of the $K_{\beta}$ components.

After the optimum selection of the $K_{\beta}$ components for Ba and La, their lines were subtracted from the original spectrum by the least squares method. The difference represents the true intensity spectrum of the $\mathrm{Pr}$ and $\mathrm{Nd} K_{\alpha}$ lines (Fig. 3C). An analogous procedure for the determination of the true spectrum in the region of the Sm lines is shown in Fig.4.

None of the soil reference standards was certified for $\mathrm{Pr}, \mathrm{Nd}$, and $\mathrm{Sm}$; only three rock standards were certified for $\mathrm{Nd}$; and one rock standard was certified for Pr and Sm. Therefore, the correlation between the intensities of the spectral lines and the concentrations of the elements cannot be found by conventional methods. 
We proposed a generalized calibration curve to be used. The values of the analytical parameter (the ratio between the spectral line intensity and the incoherently scattered exiting radiation intensity) determined by the standard background method as functions of the $\mathrm{La}, \mathrm{Ce}, \mathrm{Pr}, \mathrm{Nd}$, and Sm concentrations for the set of reference standards are shown in Fig. 5. It can be seen that the points for La and Ce (elements sufficiently certified in the reference standards) lie on the generalized curve with good accuracy. All the known points for Pr and $\mathrm{Nd}$ also lie on the generalized curve. It can be concluded that the relationship between the analytical parameter and the element concentration will be the same for five lanthanides: $\mathrm{La}, \mathrm{Ce}, \mathrm{Pr}, \mathrm{Nd}$, and $\mathrm{Sm}$. This conclusion is well founded if the closeness of the lines of these elements in the energy spectrum and the remoteness of the exiting radiation are taken into consideration.
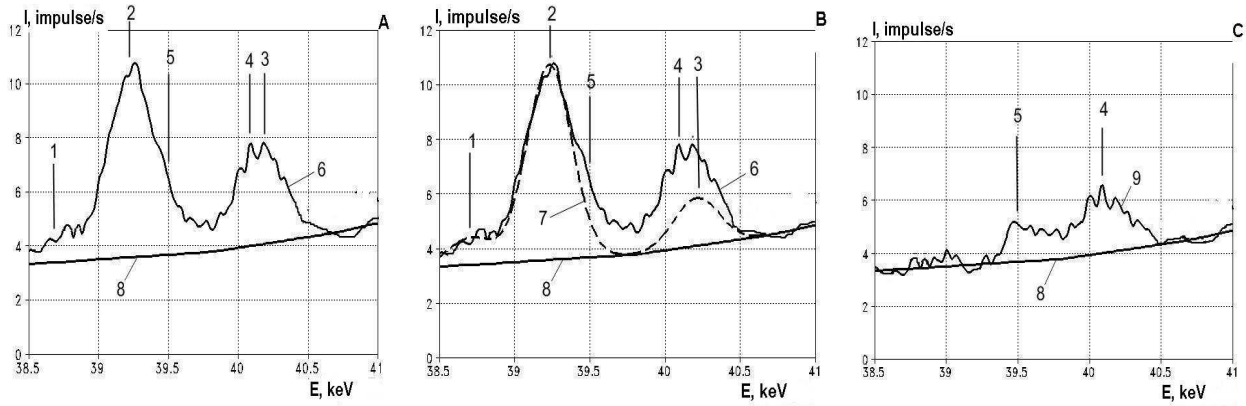

Fig. 4. Spectral segment for the Sm identification (the same sample as in Fig. 3): (A) general spectrum view; (B) detailed interpretation of the spectrum with the simulation of the $K_{\beta}$ components of the La and Ce lines; (C) the spectrum after the subtraction of the $K_{\beta}$ components. The spectral lines: (1) La $K_{\beta 2} ;$ (2) Ce $K_{\beta 1}$; (3) Ce $K_{\beta 2} ;$ (4) Sm $K_{\alpha 1}$; (5) Sm $K_{\alpha 2}$. (6) the original spectrum obtained by the energy dispersive analyzer; (7) simulation of the $K_{\beta}$ components of the La and Ce lines;(8) approximation of the background radiation; (9) true spectrum after the subtraction of the $K_{\beta}$ components.
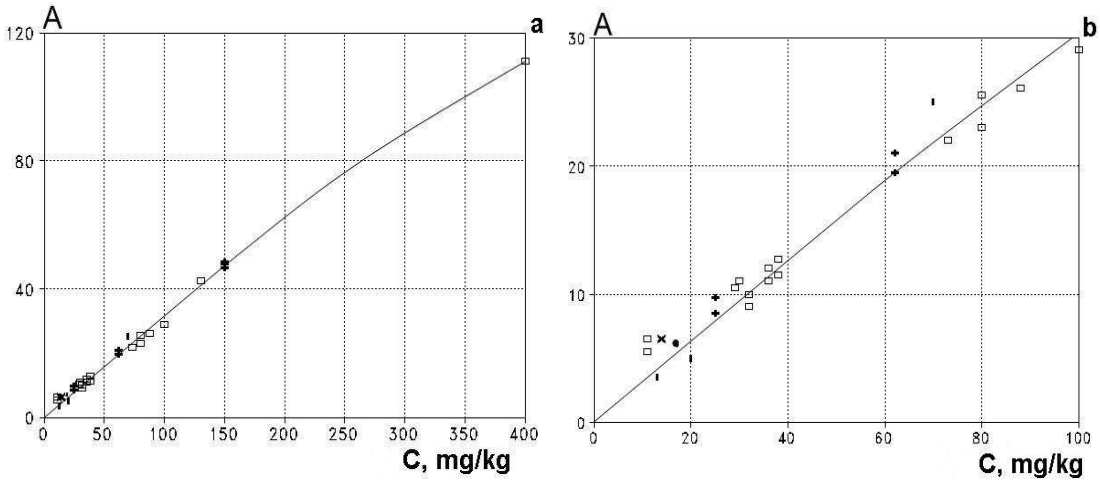

Fig. 5. The analytical parameter (the ratio between the spectral line intensity and the incoherently scattered exiting radiation intensity) as a function of the element concentration: ( $\square$ ) La; (+) Ce; (×) Pr; (I) Nd; ( ) Sm. (a) general view for the set of reference standards; (b) detailed view of the initial part of the curve. 
The error of determining $\mathrm{Pr}, \mathrm{Nd}$, and $\mathrm{Sm}$ cannot be estimated by the conventional method because of the insufficient certification of the reference standards for $\mathrm{Pr}, \mathrm{Nd}$, and $\mathrm{Sm}$. The estimation can be based only on indirect considerations. The previously determined values of the $K$-factors are 1.02 for La and 1.07 for Ce . This implies that, first, the determination the error of these elements almost completely consists of the determination of the error of the spectral line intensity; i.e., the relationship between the analytical parameter and the element concentration (generalized calibration curve) is selected adequately. Second, the values of the $K$-factors show that an almost ultimate accuracy was reached in the measurements of the line intensities. For the Poisson process of the pulse counting in an energy dispersive analyzer, the absolute error of the intensity measurement is equal to the square root of the intensity. The accuracy of the intensity measurements for $\mathrm{Pr}, \mathrm{Nd}$, and Sm will obviously be worse than those for La and Ce, because the intensity of the latter elements is measured after the subtraction of the superimposed lines; the value of the $K$-factor for them can be estimated as 2 .

The metrological parameters were then improved by increasing the time of the spectrum accumulation. The improvement of the parameters was proportional to the square root of the accumulation time. For the samples with low contents of the elements determined, the time of the spectrum accumulation in the ReSPEKT analyzer was increased to $1.5 \mathrm{~h}$.

\section{Key results}

\subsection{Background soils}

Podzolization is one of the leading elementary soil forming processes in the forest zone. It is considered to develop due to metal complexing with organic ligands. At present, the following main properties of the podzolic horizon are distinguished: (1) the light gray and whitish color of the horizon (instead of a red or yellowbrown one) due to Fe and Mn removal and the residual accumulation of silica; (2) the acid soil reaction of this horizon and the substantial base unsaturation; and (3) the depletion in nutrients, sesquioxides, and clay particles (Kaurichev, 1989). Fe and $\mathrm{Al}$ migrate with the organic complexes from the eluvial to the illuvial horizon. This is also true for $\mathrm{K}, \mathrm{Na}, \mathrm{Ca}$, and $\mathrm{Mg}$. The podzol formation is assessed according to the degree of the profile differentiation of the iron and aluminum. Special attention is historically paid to $\mathrm{Fe}, \mathrm{Al}, \mathrm{K}, \mathrm{Na}$, and $\mathrm{Mg}$, because the investigation of the soil chemical composition started with measurements of the total content of macroelements.

Later, the development of the cheap express method of X-ray fluorescence analysis permitted obtaining reliable data on the content of heavy metals in podzolic soils. However, the study with this method was somehow misbalanced, as not all heavy metals were involved in investigation in podzolic soils, and an important group of rare earth metals (yttrium and lanthanides) was omitted (Perel'man, 1975). The situation somewhat improved after researchers began to study lanthanides (La and $\mathrm{Ce}$ ) using X-ray radiometric analysis.

The analysis of the redistribution of specific heavy metals (including the rare earth elements) upon podzolization will facilitate the better understanding of the complex soilformation process and revealing its additional identification criteria.

We studied the taiga soils with eluvial-illuvial profile differentiation in two regions of the European part of Russia, i.e., Arkhangel'sk oblast (the northern taiga) and the Perm region (the southern taiga). 
Two soils were investigated in the Pinega district of Arkhangel'sk oblast: an ironilluvial podzol formed on alluvial sandy deposits of a river terrace (further referred to as the podzol) under a 40-yearold pine forest that was transformed by numerous fires. A podzolic contact bleached soil with a podzol microprofile (further called the podzolic soil) formed on twolayer moraine (loamy sand / sandy heavy loam) under a spruce forest. The $E_{\mathrm{pyr}}$ horizon in the podzol contains many charcoal inclusions, and different horizons (BHFn and BF) are identified at a depth of $5-15 \mathrm{~cm}$ at different profile walls. The podzol formed on sand is characterized by an acid and weakly acid (in the BC horizon) soil reaction. In the podzolic soil on the two member deposits, the soil reaction varies from acid (to a depth of $16 \mathrm{~cm}$ ) to neutral (deeper than $30 \mathrm{~cm}$ ). Some properties of these soils are described in detail in (Goryachkin, Pfeifer, 2005).

The soddypodzolic loamy soil was studied in the town of Chusovoi in the Perm region in the woodland park on the left bank of the Chusovaya River. The soil is acidic to a depth of $85 \mathrm{~cm}$, and deeper the soil reaction is neutral.

Podzol, Pinega. This soil is specified by a low content of heavy metals, which is below their clarkes. Even the illuvial horizons are depleted in $\mathrm{Ni}, \mathrm{Cu}, \mathrm{Ga}, \mathrm{Zr}, \mathrm{Pb}, \mathrm{Fe}, \mathrm{Al}, \mathrm{Sr}, \mathrm{Ba}, \mathrm{Y}, \mathrm{La}$, and Ce. The low content of heavy metals is controlled by the light texture of the podzol.

Podzolic soil, Pinega. The content of heavy metals is higher in this soil than in the sandy podzol. The list of metals whose content is below the clarke is much shorter: $\mathrm{Ni}, \mathrm{Zr}, \mathrm{Pb}, \mathrm{Sr}$, $\mathrm{Y}$, and La (Table 2). This is related to the heavy soil texture and, consequently, the lower initial sorting of the moraine substratum.

The soddypodzolic soil in the town of Chusovoi. The content of heavy metals is the highest in this soil. The list of metals whose content is below their clarke values is very short- $\mathrm{Zr}, \mathrm{Sr}, \mathrm{Y}$, and $\mathrm{Ba}$ (Table 2) - which is explained by the heavy texture of the soil.

The average content of these metals in the podzolic soils is below their clarke values. The content of Ce is the highest $(29 \mathrm{mg} / \mathrm{kg})$, La ranks second $(18 \mathrm{mg} / \mathrm{kg})$, and Y ranks third (16 $\mathrm{mg} / \mathrm{kg}$ ). The higher content of La than $\mathrm{Y}$ in the soils is worth noting, although the clarke of $\mathrm{Y}$ equal to $40 \mathrm{mg} / \mathrm{kg}$ (we consider it to be overestimated) exceeds the clarke of La (34 $\mathrm{mg} / \mathrm{kg}$ ). In this connection, let us point out that the clarke of $\mathrm{Y}$ is only $25 \mathrm{mg} / \mathrm{kg}$ in the soils of the USA (Ivanov, 1997). The geochemical closeness of $Y$ and La mentioned in publications is proved by the high correlation coefficient between them in the podzolic soils $(r=0.90)$.

We may state that the podzolic soils are depleted in the rareearth metals. In spite of this, the rareearth metals respond readily to the soil podzolization.

As seen in Table 2, the metals differ significantly by their participation in the podzolization process. Let us divide them into three groups according to the illuviation index value. $K_{\text {ill }}>$ 5 for the metals participating actively in podzolization; $5>K_{\text {ill }}>1.5$ for the metals that are moderately active, and $K_{\text {ill }}<1.5$ for the metals virtually not participating in this process.

Let us list the data about the illuviation coefficients of the metals into a summary table (Table 3) in which the metals are divided into three groups according to the degree of their participation in the eluvial-illuvial profile differentiation. This table also manifests the variation coefficients of the illuviation index $K_{\mathrm{ill}}$. They show the variation degree of the 
eluvial-illuvial distribution of the same metals in different soils. This is evidently related to the different share of reactive metal particles in the different soils.

\begin{tabular}{|c|c|c|c|c|}
\hline Horyzon & Depth, cm & $\mathrm{Y}$ & $\mathrm{La}$ & $\mathrm{Ce}$ \\
\hline \multicolumn{5}{|c|}{ Podzol, Pinega } \\
\hline $\mathrm{E}_{\mathrm{pyr}}$ & $0-2$ & 10 & 7 & 10 \\
\hline $\mathrm{E}$ & $2-5$ & 5 & 5 & 6 \\
\hline BHFn & $5-13$ & 9 & 11 & 12 \\
\hline $\mathrm{BF}$ & $6-10$ & 10 & 13 & 17 \\
\hline $\mathrm{BC}$ & $13-36$ & 7 & 7 & 9 \\
\hline Bce & $36-49$ & 8 & 12 & 20 \\
\hline $\mathrm{D}$ & $49-110$ & 11 & 15 & 24 \\
\hline Clarke & & 40 & 34 & 43 \\
\hline $\mathrm{C}_{\mathrm{BF}}: \mathrm{C}_{\mathrm{el}}$ & & 2.0 & 2.6 & 2.8 \\
\hline \multicolumn{5}{|c|}{ Podzolic soil, Pinega } \\
\hline Ele & $0-6$ & 14 & 13 & 18 \\
\hline ELf & $6-16$ & 17 & 14 & 19 \\
\hline $2 E L$ & $16-20$ & 16 & 21 & 37 \\
\hline 2ELBT & $20-30$ & 20 & 24 & 44 \\
\hline 2BT1 & $30-65$ & 22 & 29 & 53 \\
\hline 2BT2 & $65-90$ & 24 & 33 & 54 \\
\hline $2 \mathrm{BC}$ & $90-130$ & 20 & 31 & 47 \\
\hline Clarke & & 40 & 34 & 49 \\
\hline $\mathrm{C}_{\mathrm{ELBT}}: \mathrm{C}_{\mathrm{el}}$ & & 1.4 & 1.8 & 2.4 \\
\hline \multicolumn{5}{|c|}{ Soddypodzolic soil, Chusovoi } \\
\hline AY & $3-12$ & 18 & 15 & 23 \\
\hline EL & $12-27$ & 18 & 21 & 30 \\
\hline BEL & $27-59$ & 22 & 21 & 36 \\
\hline BT1 & $59-85$ & 36 & 38 & 53 \\
\hline BT2 & $85-104$ & & 30 & 40 \\
\hline $\mathrm{C}$ & $104-150$ & 23 & 20 & 32 \\
\hline Clarke & & 40 & 34 & 43 \\
\hline $\mathrm{K}_{\text {ill }}$ & & 2.0 & 2.5 & 2.3 \\
\hline
\end{tabular}

Table 2. Content of lanthanides (mg/kg) in the studied soil (podzol, Pinega; podzolic soil, Pinega and soddypodzolic soil, Chusovoi).

Factors influencing the profile redistribution of heavy metals. We studied the influence of the following factors: the $\mathrm{pH}$, the content of clay particles, the organic carbon, and the iron (both total and oxalatesoluble). We calculated the pair correlation coefficients between these soil parameters and the content of lanthanides (using Excel-2007-software). To rule out the impact of the lithogenic factor, the statistical bonds were considered only for the upper horizons. The reliability level was taken for probability of $P=0.95$ (Table 4). 
Lanthanides in Soils: X-Ray Determination,

\begin{tabular}{|c|c|c|c|}
\hline Metal & Values & Mean & $\begin{array}{c}\text { Variation } \\
\text { coefficient, \% }\end{array}$ \\
\hline \multicolumn{4}{|c|}{ Highly active metals } \\
\hline $\mathrm{Mn}$ & $33 ; 4.5 ; 1.3$ & 12.9 & 135 \\
\hline $\mathrm{Fe}$ & $4.7 ; 4.2 ; 18$ & 9.0 & 87 \\
\hline $\mathrm{Cr}$ & $12 ; 5.9 ; 1.4$ & 6.4 & 83 \\
\hline $\mathrm{Zn}$ & $14 ; 3,7 ; 1.3$ & 6.3 & 106 \\
\hline \multicolumn{4}{|c|}{ Moderately active metals } \\
\hline $\mathrm{Cu}$ & $4.3 ; 4.5 ; 2.1$ & 3.6 & 37 \\
\hline $\mathrm{Ni}$ & $4.0 ; 2.3 ; 2.8$ & 3.0 & 29 \\
\hline $\mathrm{Ce}$ & $2.8 ; 2.4 ; 2.3$ & 2.5 & 11 \\
\hline $\mathrm{La}$ & $2.6 ; 1.8 ; 2.5$ & 2.3 & 19 \\
\hline $\mathrm{Y}$ & $2.0 ; 2.0 ; 2.0$ & 2.0 & 0 \\
\hline $\mathrm{Pb}$ & $2.5 ; 1.8 ; 1.5$ & 1.9 & 27 \\
\hline $\mathrm{Al}$ & $2.5 ; 1,4 ; 1.5$ & 1.8 & 34 \\
\hline $\mathrm{Zr}$ & $3.3 ; 1.2 ; 1.0$ & 1.8 & 70 \\
\hline $\mathrm{Ga}$ & $1.4 ; 1.0 ; 2.3$ & 1.6 & 41 \\
\hline \multicolumn{4}{|c|}{ Inert metals } \\
\hline $\mathrm{Sr}$ & $1.4 ; 1.1 ; 1.0$ & 1.2 & 17 \\
\hline $\mathrm{Ba}$ & $1.3 ; 1.1 ; 1.0$ & 1.1 & 14 \\
\hline
\end{tabular}

Table 3. Values of the illuviation coefficient $\mathrm{K}_{\mathrm{ill}}$ of the metals in the soils of the podzolic group (podzol, Pinega; podzolic soil, Pinega and soddypodzolic soil, Chusovoi).

In the sandy podzol lanthanum is accumulated in the fine silt. In the texturally differentiated podzolic soils the content of lanthnides depends on the $\mathrm{pH}$ of the soil solution. The contents $\mathrm{La}$ and $\mathrm{Ce}$ (which respond to the acidification of soil in the podzolic horizon) depend reliably on the $\mathrm{pH}$ value. These metals are cationogenic, with their mobility growing upon the soil's acidification. The content $Y$ is also reliably connected to the amount of clay particles. In soddypodzolic soil, the content of lanthanides Y, La and Ce depends on the soil ferrugination; these metals act as siderophores.

The classic definition of podzolization as a process of iron and aluminum oxides destruction and removal of the decay products should be supplemented by the phenomena of leaching of a number of heavy metals. In addition to $\mathrm{Fe}$ and $\mathrm{Al}$, many heavy metals manifest well pronounced eluvial-illuvial redistribution in podzolic soils $\mathrm{Mn}, \mathrm{Cr}, \mathrm{Zn}, \mathrm{Cu}, \mathrm{Ni}, \mathrm{Ce}, \mathrm{La}$, and $\mathrm{Y})$. The dimensions of these heavy metals' redistribution exceed that of Al. The inactive participation of $\mathrm{Al}$ in the redistribution is explained by the insignificant share of its reactive fraction. Although the soils of the podzolic group are depleted in the rare earth metals, the latter readily respond to soil podzolization. In a sandy podzol, the degree of leaching of such heavy metals as $\mathrm{Mn}, \mathrm{Cr}, \mathrm{Zn}, \mathrm{Ni}$, and $\mathrm{Zr}$ is markedly higher than in loamy podzolic soil. The leaching of heavy metals from the podzolic horizons has a diagnostic significance, whereas the depletion of metals participating in plant nutrition and biota development is of ecological importance. 


\begin{tabular}{|c|c|c|c|}
\hline Factor & $\mathrm{Y}$ & $\mathrm{La}$ & $\mathrm{Ce}$ \\
\hline \multicolumn{4}{|c|}{ Podzol, Pinega } \\
\hline $\mathrm{pH}_{\text {water }}$ & -0.08 & 0.40 & 0.33 \\
\hline $\mathrm{C}_{\text {org }}$ & 0.64 & 0.04 & 0.10 \\
\hline $\mathrm{Fe}_{\text {tot }}$ & 0.52 & 0.77 & 0.59 \\
\hline Clay & 0.49 & 0.42 & 0.29 \\
\hline Fine silt & 0.55 & $0.94^{*}$ & 0.83 \\
\hline Medium silt & 0.52 & 0.85 & 0.86 \\
\hline Coarse silt & 0.44 & 0.53 & 0.55 \\
\hline Fine sand & 0.48 & 0.67 & 0.75 \\
\hline $\begin{array}{l}\text { Medium and } \\
\text { coarse sand }\end{array}$ & -0.55 & -0.72 & -0.78 \\
\hline \multicolumn{4}{|c|}{ Podzolic soil, Pinega } \\
\hline $\mathrm{pH}_{\text {water }}$ & 0.82 & $0.98^{*}$ & $0.98^{*}$ \\
\hline $\mathrm{C}_{\text {org }}$ & -0.56 & -0.87 & -0.90 \\
\hline $\mathrm{Fe}_{\text {tot }}$ & 0.74 & 0.48 & 0.45 \\
\hline Clay & $0.95^{*}$ & 0.78 & 0.74 \\
\hline Fine silt & 0.64 & 0.36 & 0.33 \\
\hline Medium silt & -0.75 & -0.84 & -0.81 \\
\hline Coarse silt & -0.42 & -0.23 & -0.16 \\
\hline Fine sand & -0.96 & -0.76 & -0.74 \\
\hline $\begin{array}{l}\text { Medium and } \\
\text { coarse sand }\end{array}$ & -0.91 & -0.70 & -0.65 \\
\hline \multicolumn{4}{|c|}{ Soddypodzolic soil, Chusovoi } \\
\hline $\mathrm{pH}_{\text {water }}$ & -0.18 & -0.36 & -0.37 \\
\hline $\mathrm{C}_{\text {org }}$ & -0.43 & -0.52 & -0.61 \\
\hline $\mathrm{Fe}_{\text {tot }}$ & $0.94^{*}$ & $0.89^{*}$ & $0.96^{*}$ \\
\hline Clay & 0.85 & 0.86 & $0.93^{*}$ \\
\hline Fine silt & -0.60 & -0.40 & -0.49 \\
\hline Medium silt & -0.81 & -0.64 & -0.76 \\
\hline Coarse silt & -0.46 & -0.59 & -0.61 \\
\hline Fine sand & -0.52 & -0.69 & -0.68 \\
\hline $\begin{array}{l}\text { Medium and } \\
\text { coarse sand }\end{array}$ & -0.56 & -0.57 & -0.69 \\
\hline
\end{tabular}

${ }^{*}$ reliable for $P=95 \%$.

Table 4. Pair correlation coefficients between the content of lanthanides and the $\mathrm{pH}_{\text {water }}$ the content of clay particles, and the organic carbon in the soils' studied (podzol, Pinega; podzolic soil, Pinega and soddypodzolic soil, Chusovoi).

Leaching of heavy metals is most closely related to the destruction of clay particles (in heavy textured podzolic soils in particular); the soil's acidity's influence is less noticeable. 


\subsection{Soils from natural positive geochemical anomalies}

\subsubsection{Tundra soils of the Kolyma Lowland}

Gley and peat gley cryozems were sampled in tundra of the Kolyma Lowland. Nineteen samples of the fine earth were studied. The soils were described in detail in (Vodyanitskii, Mergelov et al., 2008).

Data on the concentrations of La and Ce in these soils are given in Table 5, and their statistical characteristics are presented in Table 6. The mean element concentrations are high. The accumulation of lanthanides is even more pronounced. Thus, the average concentrations of La and Ce in cryozems reach 46 and $79 \mathrm{mg} / \mathrm{kg}$, which is considerably higher than the clarke values of these elements in the pedosphere $(26$ and $49 \mathrm{mg} / \mathrm{kg}$ ) and in the lithosphere (35 and $66 \mathrm{mg} / \mathrm{kg}$, respectively). Hence, the tundra zone of the Kolyma lowland is an example of a positive geochemical anomaly of lanthanides.

\begin{tabular}{|c|c|c|c|}
\hline Horizon & Depth, $\mathrm{cm}$ & $\mathrm{La}$ & $\mathrm{Ce}$ \\
\hline \multicolumn{4}{|c|}{ Gleyed cryozem, pit T6P2 } \\
\hline Gox & $40-50$ & 49 & 79 \\
\hline $\mathrm{Cr}(\mathrm{Cg})$ & $50-70$ & 49 & 75 \\
\hline \multicolumn{4}{|c|}{ Gleyed cryozem, pit T8P1 } \\
\hline Gox & $3-10$ & 47 & 74 \\
\hline \multirow[t]{2}{*}{ CR } & $10-16$ & 48 & 72 \\
\hline & $16-33$ & 46 & 71 \\
\hline Gox & $33-42$ & 51 & 71 \\
\hline $\mathrm{Cr}(\mathrm{Cg})$ & $42-52$ & 44 & 66 \\
\hline \multicolumn{4}{|c|}{ Gleyed cryozem, pit T9P3 } \\
\hline CR & $0.5-3$ & 43 & 66 \\
\hline $\mathrm{CRg}_{\prime \prime}$ & $3-10$ & 45 & 66 \\
\hline CR & $10-35$ & 42 & 64 \\
\hline $\mathrm{CRg}_{\prime \prime \prime}$ & $35-54$ & 46 & 71 \\
\hline $\mathrm{Cr}(\mathrm{Cg})$ & $54-59$ & 49 & 71 \\
\hline \multicolumn{4}{|c|}{ Gleyed cryozem, pit T10P3 } \\
\hline \multirow[t]{2}{*}{$\mathrm{CRg}_{\prime \prime}$} & $8-18$ & 44 & 69 \\
\hline & $18-35$ & 50 & 74 \\
\hline $\mathrm{Cr}(\mathrm{Cg})$ & $58-60$ & 46 & 70 \\
\hline \multicolumn{4}{|c|}{ Peat gleyed cryozem, pit T9P5 } \\
\hline $\mathrm{CRg}_{\prime \prime}$ & $12-23$ & 48 & 69 \\
\hline $\mathrm{Cr}(\mathrm{Cg})$ & $23-35$ & 46 & 67 \\
\hline \multicolumn{4}{|c|}{ Peat gley soil, pit T9P7 } \\
\hline \multirow[t]{2}{*}{ Gox } & $10-17$ & 42 & 59 \\
\hline & $17-45$ & 46 & 71 \\
\hline
\end{tabular}

Table 5. The contents of La and Ce in cryozems of the Kolyma Lowland, mg/kg.

The loss of lanthanides from the soil profile is favored by peat formation and gleyzation. For $\mathrm{Ce}$, the mean concentrations in the cryozems and in the gley horizons of peat gley soils are equal to 71 and $66 \mathrm{mg} / \mathrm{kg}$; and for $\mathrm{La}-47$ and $45 \mathrm{mg} / \mathrm{kg}$, respectively. However, these differences are statistically unreliable and may be considered a weakly pronounced tendency. 
It should be noted that the concentrations of La and Ce in the studied tundra soils are low variable (Table 6): the variation coefficients are equal to $5-6 \%$, which points to the weak differentiation of these elements in the soil profiles.

\begin{tabular}{|c|c|c|c|}
\hline Element & Mean & Range & $\begin{array}{c}\text { Variation } \\
\text { coefficient, } \%\end{array}$ \\
\hline \multicolumn{3}{|c|}{$\mathrm{mg} / \mathrm{kg}$} \\
\hline \multicolumn{5}{|c|}{ Gleyed cryozems } \\
\hline Lanthanum & 47 & $43-51$ & 5.7 \\
\hline Cerium & 71 & $64-75$ & 5.6 \\
\hline \multicolumn{7}{|c|}{ Peat gley soils } \\
\hline Lanthanum & 45 & $42-48$ & 5.6 \\
\hline Cerium & 66 & $59-71$ & 8.0 \\
\hline
\end{tabular}

Table 6. Statistical characteristics of the La and Ce contents in cryozems of the Kolyma Lowland.

\subsubsection{The Kola Peninsula soils}

The contents of lanthanides in the soils were determined in northern taiga region: the Khibiny-Lovozero province (Kola Peninsula), where the soils of the background area were studied. On the eastern bank of Lake Umbozero, peatpodzolic soils were sampled (profiles 10 and 11); in the region of a geochemical anomaly due to the closeness to a deposit of loparite ores, samples were taken in three places: a soddy podbur was sampled on the western bank of Lake Lovozero (profile 2); a peaty podzolic soil was sampled on the northern bank of Lake Seidozero (profile 5), and a podzol was sampled on the bank of the Elmoraiok River (profile 9). All the soils were acid $\left(\mathrm{pH}_{\text {water }} 3.6-5.6\right)$ with light sandy and loamy sandy textures. Only the mineral horizons of the soils were analyzed (Table 7).

The background soils and those of the geochemical anomaly formed under the effect of the Lovozero deposit of loparite ores were studied. The content of rare earth metals in loparite is very high (up to $35 \%$ in terms of the element oxides). The average chemical composition of loparite with the conventional formula $\mathrm{NaCeTi}_{2} \mathrm{O}_{6}$ (Ivanov, 1997) is as follows (in terms of oxides, \%): rare earth metals - 30; $\mathrm{Ti}-40 ; \mathrm{Nb}-12 ; \mathrm{Na}-8$; $\mathrm{Sr}-3$; $\mathrm{Ca}-5$; and $\mathrm{Ta}-0.8$. Among the rare earth elements, Ce is predominant (rel. \%): Ce - 49.6; $\mathrm{La}-28.4 ; \mathrm{Pr}-3.4 ; \mathrm{Nd}-15.5$; and $S m-2.4$.

Because of the enrichment of loparite with rare earth metals, their contents exceed the clarke values for the earth's crust by many times: Ce - 133900:66 = 2030; La - $76700: 35=2190 ; \mathrm{Pr}$ - $9180: 9=1020 ; \mathrm{Nd}-41850: 40=1050$; and Sm - $6480: 7=926$. Thus, the loparite containing parent rocks can be significantly enriched with lanthanides, especially the lightest ones (Ce and La). The enrichment of loparite with $\mathrm{Pr}, \mathrm{Nd}$, and $\mathrm{Sm}$ is twice lower, although it reaches 1000 times. The geochemical anomaly can be heterogeneous because of the different occurrence depths of loparites.

Table 7 shows that the content of Pr in the upper horizons of the soils in the background area is lower than the clarke value by 2 times, and that of $\mathrm{Nd}$ by 3 times; the content of $\mathrm{Sm}$ is below the detection limit (lower than $1 \mathrm{mg} / \mathrm{kg}$ ). An eluvial distribution of lanthanides was observed in some of the profiles studied. A similar situation was previously observed in 
podzolic soils of Sweden and the Kola Peninsula (Nikonov et al., 1999; Tyler, 2004b). Based on the hypothesis about the original layer structure, Sweden soil scientists estimated the losses of lanthanides. A podzol lost $40-50 \%$ of the initial contents of $\mathrm{Y}, \mathrm{La}, \mathrm{Ce}, \mathrm{Nd}, \mathrm{Pr}$, and $\mathrm{Sm}$ over 14000 years (Tyler, 2004a). An analogous calculation shows that $36-47 \%$ of the $\mathrm{Nd}$ and $0-54 \%$ of the Pr were leached from the E horizon of peatpodzolic soils in the Khibiny-Lovozero province; $53 \%$ of the $\mathrm{Nd}, 60 \%$ of the Pr, and $50 \%$ of the Sm were leached from the E horizon of a podzol. The instability of lanthanides in the acid soils of the taiga zone was confirmed.

\begin{tabular}{|c|c|c|c|c|c|c|c|c|c|}
\hline Horizon & Depth, cm & $\operatorname{Pr}$ & $\operatorname{Pr}_{\mathrm{s}}: \operatorname{Pr}_{\mathrm{c}}$ & $\mathrm{Nd}$ & $\mathrm{Nd}_{\mathrm{s}}: \mathrm{Nd}_{\mathrm{c}}$ & Sm & $S m_{s}: S m_{c}$ & $\operatorname{Pr}: \mathrm{Nd}$ & $\operatorname{Pr}: S m$ \\
\hline \multicolumn{10}{|c|}{ Background Profile 10. Umbozero bank. Peatpodzolic soil } \\
\hline $\mathrm{E}$ & $12-18$ & 4 & 0.53 & 8 & 0.42 & - & - & 0.50 & - \\
\hline BT & $18-28$ & 2 & 0.26 & 7 & 0.37 & - & - & 0.29 & - \\
\hline $\mathrm{C}$ & $28-47$ & 4 & 0.53 & 15 & 0.79 & - & - & 0.27 & - \\
\hline \multicolumn{10}{|c|}{ Profile 11. Umbozero bank. Peatpodzolic soil } \\
\hline $\bar{E}$ & $8-10$ & 3 & 0.42 & 7 & 0.37 & - & - & 0.43 & - \\
\hline BT & $10-29$ & 3 & 0.42 & 6 & 0.32 & - & - & 0.50 & - \\
\hline $\mathrm{C}$ & $29-49$ & 3 & 0.42 & 11 & 0.58 & - & - & 0.27 & - \\
\hline \multicolumn{10}{|c|}{ Geochemical anomaly Profile 2. Lovozero bank. Soddy podbur } \\
\hline AY & $5-12$ & 14 & 1.8 & 44 & 2.3 & 11 & 2.4 & 0.32 & 1.27 \\
\hline $\mathrm{BF}$ & $12-40$ & 13 & 1.7 & 57 & 3.0 & 10 & 2.2 & 0.23 & 1.30 \\
\hline $\mathrm{BC}$ & $40-50$ & 12 & 1.6 & 59 & 3.1 & 10 & 2.2 & 0.20 & 1.20 \\
\hline \multicolumn{10}{|c|}{ Profile 5. Seidozero bank. Peatpodzolic soil } \\
\hline $\mathrm{E}$ & $13-24$ & 21 & 2.7 & 104 & 5.5 & 18 & 4.0 & 0.20 & 1.17 \\
\hline BT & $24-40$ & 30 & 3.9 & 142 & 7.5 & 23 & 5.1 & 0.21 & 1.30 \\
\hline C & $40-62$ & 46 & 6.0 & 198 & 10.4 & 35 & 7.8 & 0.23 & 1.31 \\
\hline \multicolumn{10}{|c|}{ Profile 9. Elmoraiok River bank. Podzol } \\
\hline $\mathrm{E}$ & $5-15$ & 22 & 2.9 & 106 & 5.6 & 16 & 3.5 & 0.21 & 1.37 \\
\hline BT & $15-30$ & 36 & 4.7 & 156 & 8.2 & 26 & 5.8 & 0.23 & 1.38 \\
\hline $\mathrm{C}$ & $30-52$ & 55 & 7.2 & 224 & 11.8 & 32 & 7.1 & 0.24 & 1.72 \\
\hline Clarke (c) & & 9 & & 40 & & 7.0 & & 0.22 & 1.29 \\
\hline Clarke (s) & & 7.6 & & 19 & & 4.5 & & 0.40 & 1.69 \\
\hline
\end{tabular}

Table 7. Pr, Nd, and Sm in the mineral horizons of soils in the Khibiny-Lovozero province, $\mathrm{mg} / \mathrm{kg}$.

In the Lovozero geochemical anomaly, the contents of $\mathrm{Pr}, \mathrm{Nd}$, and $\mathrm{Sm}$ in the mineral horizons exceed the clarke values. In the soddy podbur on the Lovozero bank, their contents are higher than the clarkes by 1.6-1.8 times for Pr, 2.2-2.4 times for Sm, and by 2.3-3.1 times for $\mathrm{Nd}$. The concentrations of lanthanides in the peatpodzolic soil on the bank of Lake Seidozero and in the podzol on the bank of the Elmoraiok River are even higher. Here, the clarke values are exceed by 2.7-7.2 times for Pr, by 4-7.8 times for Sm, and even by 5.5-11.8 times for $\mathrm{Nd}$. Thus, the soils are strongly enriched with these lanthanides, especially $\mathrm{Nd}$.

The statistical relationships with a wide range of lanthanides studied previously were considered. In the background area, $\mathrm{Y}$ was related to $\mathrm{La}$ and $\mathrm{Ce}$, and $\mathrm{La}$ was related to $\mathrm{Ce}$ with high reliability $(r=0.83-0.96)$. The content of Pr, on the contrary, was not related to any lanthanide. The peculiar behavior of $\mathrm{Pr}$ in the soil can be related to its increased biophilicity. 
Let us discuss the reason for the difference in the distributions of $\operatorname{Pr}$ and $\mathrm{Nd}$, although their contents in loparite, the main rare earth mineral of the province, are similar with consideration for their clarkes. The difference in the biophilic properties of the lanthanides is a probable reason. No reliable data are available on the biophilic properties of lanthanides. The coefficients of the biological absorption of lanthanides are absent in the revue of Perel'man (1975). This group of elements was called biotrophic (biophilic). Phosphorus is a known biophil with a high coefficient of biological absorption ( 100) (Perel'man, 1975); therefore, it can be taken that lanthanides are also biophils for some plants. This is also true for mosses and peatforming plants in the Khibiny-Lovozero province. According to Dyatlova et al. (1988), the content of Sm in the moss and lichen ash is $2-40 \mathrm{mg} / \mathrm{kg}$ (its clarke is only $7 \mathrm{mg} / \mathrm{kg}$ ), and the content of $\mathrm{Nd}$ is $8-150 \mathrm{mg} / \mathrm{kg}$ (its clarke is $19 \mathrm{mg} / \mathrm{kg}$ ). This confirms the biophilic character of lanthanides.

The degrees of biophilicity of lanthanides can be different. The comparison of the Pr and $\mathrm{Nd}$ clarkes in the soil and the earth's crust indicates the different degrees of their global persistence in soils. The index of accumulation/dispersion in the soil, IA = Clarke (soil) : Clarke (earth crust), is $19: 40=0.47$ for $\mathrm{Nd}$ and $7.6: 9=0.84$ for Pr. Our data confirm the thesis about the higher biophilicity of Pr compared to Nd. The analysis of the ash of lowash peats from the surface of peatpodzolic soils showed a difference in the biological absorption coefficients $\mathrm{A}_{\mathrm{x}}$ (against the earth's crust clarke) of these two lanthanides: $\mathrm{A}_{\mathrm{Pr}}=1.1$ and $\mathrm{A}_{\mathrm{Nd}}=$ 0.5 on the average for the background area; $A_{\mathrm{Pr}}=3.3$ and $\mathrm{A}_{\mathrm{Nd}}=2.7$ for the anomaly area. There is no reliable correlation between the contents of Pr and Nd: $r=0.47$.

In the profile of the peatpodzolic soils in the background area and the soddy podbur in the anomaly, the distribution of $\mathrm{Pr}$ is uniform, and that of $\mathrm{Nd}$ is eluvial, which explains the abovenoted absence of a statistical correlation between the contents of Pr and other lanthanides in the mineral layers. This can be due to the relative (biogenic?) accumulation of $\mathrm{Pr}$ in the upper layer of soils with relatively homogeneous textures: sandy soils in the background area and loamy sandy soils in the anomaly.

\subsection{Contaminated soils}

\subsubsection{Urbanozems and soddy-podzolic soils of Perm}

Urban soils (urbanozems) and soddy-podzolic soils from the city of Perm were studied. Samples from surface $(0-20 \mathrm{~cm})$ layers of soddy-podzolic soils were taken in parks in the central part of the city. Samples of urbanozems from the same depth were also taken on the lawns along roadways polluted by heavy metals in the central part of the city. To compare distribution patterns of the studied elements with those of well-known air pollutants, the contents of lead and nickel were determined in these soils by the routine X-ray fluorescence analysis. In total, twenty soil samples were studied.

In addition to $\mathrm{La}$ and $\mathrm{Ce}$, the concentrations of $\mathrm{Ba}, \mathrm{Ni}$ and $\mathrm{Pb}$ in the surface layers of these soils were determined, and their distribution patterns were compared. They differed for the two groups of metals (Table 8). The concentrations of $\mathrm{Ni}$ and $\mathrm{Pb}$ in these soils vary considerably, which is typical of urban soils, including soils of Perm (Eremchenko, Moskvina, 2005). The variation coefficients are $53 \%$ for $\mathrm{Ni}$ and $126 \%$ for $\mathrm{Pb}$. This is explained by the fact that the samples were taken not only in parks with soddy-podzolic soils but also from 
urbanozems near roads with intensive traffic. Variations in the contents of $\mathrm{Ba}, \mathrm{La}$, and $\mathrm{Ce}$ are considerably lower $(V=21-33 \%)$. Thus, the portion of metals of technogenic origin for these three elements is much lower than that for $\mathrm{Ni}$ and $\mathrm{Pb}$.

\begin{tabular}{|c|c|c|c|}
\hline \multirow{2}{*}{ Element } & Mean & Range & $\begin{array}{c}\text { Variation } \\
\text { coefficient, } \\
\%\end{array}$ \\
\cline { 2 - 4 } & \multicolumn{2}{|c|}{$\mathrm{mg} / \mathrm{kg}$} & 53 \\
\hline Nickel & 145 & $31-268$ & 126 \\
Lead & 113 & $24-630$ & 21 \\
Barium & 382 & $301-627$ & 28 \\
Lanthanum & 19 & $12-31$ & 33 \\
Cerium & 26 & $18-44$ & \\
\hline
\end{tabular}

Table 8. Statistical characteristics of the $\mathrm{Ni}, \mathrm{Pb}, \mathrm{Ba}, \mathrm{La}$ and $\mathrm{Ce}$ contents in urbanozems and soddy-podzolic soils in Perm.

Despite the presence of technogenic elements, average concentrations of $\mathrm{Ba}$, $\mathrm{La}$, and $\mathrm{Ce}$ are low and remain below the clarke values, which attests to the removal of lanthanides and Ba from the soil profiles. This regularity is especially pronounced in comparison with the soils of the Kolyma lowland. In the automorphic soils of Perm, the mean Ba and lanthanides' contents are by 1.6 and 2.4-2.7 times lower than those in the tundra soils of the Kolyma Lowland. Thus, active weathering and the removal of $\mathrm{Ba}, \mathrm{La}$, and $\mathrm{Ce}$ under conditions of humid climate are typical of these automorphic soils.

\subsubsection{Alluvial soils of Perm}

Meadow-bog alluvial soils were studied on floodplains of small rivers and the Kama River in Perm. Overall, 16 samples of the fine earth and nodules and rhyzoconcretions from these soils were examined. To judge about the accumulation or depletion of $\mathrm{Ba}, \mathrm{La}$, and $\mathrm{Ce}$ in the nodules and rhyzoconcretions, the coefficient of element accumulation $\left(\mathrm{C}_{\mathrm{ac}}\right)$ in them was calculated: $C_{a c}=C_{\text {concr }}: C_{\text {fine }}$ earth, where $C_{\text {concr }}$ and $C_{\text {fine }}$ earth are the contents of particular elements in the concretions and fine earth, respectively. The studied soils were described in (Vodaynitskii, Vasil'ev et al., 2007).

We studied fine earth and iron-manganic concretions (nodules and rhyzoconcretions) (Table 9). The content of Ba in the fine earth of soils varies from 406 to $527 \mathrm{mg} / \mathrm{kg}$, while its content in the concretions varies greatly (from 588 to $2848 \mathrm{mg} / \mathrm{kg}$ ). The coefficient of Ba accumulation in the concretions also varies considerably: from 1.2 to 6.0 barium fixation in them. Light-colored formations with a size of about $20 \mu \mathrm{m}$ were identified on their internal surface. The microanalyzer showed that these formations of composed of barite $\left(\mathrm{BaSO}_{4}\right)$. Neoformations of barite were earlier determined by Bronnikova and Targulian (2005) on the surface of cutans in podzolic soils. Barium is not typical of the soils of forest landscapes, so its accumulation in the cutans is related to the soil pollution. In the nodules from the alluvial soils, $\mathrm{Ba}$ is mainly accumulated as barite particles precipitated on the active matric of the nodules.

In the gleyed alluvial agrozem on the floodplain of the Mulyanka River polluted by wastewater, Ba redistribution in the soil profile takes place. In the fine earth, the Ba content 
is relatively stable (421-474 $\mathrm{mg} / \mathrm{kg})$. In the nodules, the concentration of Ba varies considerably and reaches its maximum $(2840 \mathrm{mg} / \mathrm{kg})$ in the $\mathrm{C} 4 \mathrm{~g}$, thorizon at a depth of $107-137 \mathrm{~cm}$. In this coarse-textured alluvial soil, Ba migrates easily to a considerable depth and is concentrated in the nodules.

\begin{tabular}{|c|c|c|c|c|c|c|c|c|}
\hline $\begin{array}{l}\text { Horizon; } \\
\text { depth, cm }\end{array}$ & Substrate & Ba & $\begin{array}{l}\mathrm{C}_{\mathrm{ac}} \\
(\mathrm{Ba})\end{array}$ & $\mathrm{La}$ & $\begin{array}{l}\mathrm{C}_{\mathrm{ac}} \\
(\mathrm{La})\end{array}$ & $\mathrm{Ce}$ & $\begin{array}{l}\mathrm{C}_{\mathrm{ac}} \\
(\mathrm{Ce})\end{array}$ & $\begin{array}{c}\mathrm{Ce} / \\
\mathrm{La}\end{array}$ \\
\hline \multicolumn{9}{|c|}{ Typical humus-gley soil on the Obva River floodplain, pit 51} \\
\hline \multirow[t]{2}{*}{$\mathrm{C} 2 \mathrm{~g}, \quad 37-75$} & Fine earth & 527 & & 37 & & 58 & & 1.6 \\
\hline & Rhyzoconcretions & 623 & 1.2 & 25 & 0.7 & 38 & 0.6 & 1.5 \\
\hline \multirow[t]{2}{*}{$\mathrm{G} \sim \sim, \quad 75-90$} & Fine earth & 523 & & 41 & & 60 & & 1.5 \\
\hline & Rhyzoconcretions & 673 & 1.3 & 14 & 0.3 & 16 & 0.3 & 1.1 \\
\hline \multicolumn{9}{|c|}{ Stratified typical alluvial soil on the Obva River floodplain, pit 53} \\
\hline $\mathrm{C} 2 \sim \sim, \quad 20-27$ & Fine earth & 410 & & 28 & & 41 & & 1.5 \\
\hline C6 , $71-78$ & Fine earth & 406 & & 26 & & 38 & & 1.5 \\
\hline \multicolumn{9}{|c|}{ Mineralized humus-gley soil on the Kama River floodplain, pit 41} \\
\hline \multirow{2}{*}{ G , $\quad 31-55$} & Fine earth & 452 & & 38 & & 57 & & 1.5 \\
\hline & Nodules & 715 & 1.6 & 56 & 1.5 & 191 & 3.3 & 3.4 \\
\hline \multicolumn{9}{|c|}{ Gleyed agrozem on the Mulyanka River floodplain, pit 33} \\
\hline \multirow[t]{2}{*}{$\mathrm{C} 2 \sim \sim, \quad 49-75$} & Fine earth & 430 & & 31 & & 47 & & 1.5 \\
\hline & Nodules & $\begin{array}{c}195 \\
7\end{array}$ & 4.5 & 104 & 3.3 & 324 & 6.9 & 3.1 \\
\hline \multirow[t]{2}{*}{ C3 , $75-107$} & Fine earth & 421 & & 31 & & 46 & & 1.5 \\
\hline & Nodules & 2120 & 5.0 & 108 & 3.5 & 302 & 6.6 & 2.8 \\
\hline \multirow[t]{2}{*}{$\begin{array}{l}C 4 g, t \sim \sim, \\
107-137\end{array}$} & Fine earth & 474 & & 34 & & 45 & & 1.3 \\
\hline & Nodules & 2840 & 6.0 & 100 & 2.9 & 243 & 5.4 & 2.4 \\
\hline \multirow[t]{2}{*}{ C5g , $\quad>137$} & Fine earth & 441 & & 30 & & 48 & & 1.6 \\
\hline & Nodules & 588 & 1.3 & 86 & 2.9 & 150 & 3.1 & 1.7 \\
\hline Average & & & 3.0 & & 2.2 & & 3.7 & \\
\hline
\end{tabular}

Table 9. The contents of $\mathrm{Ba}, \mathrm{La}$, and $\mathrm{Ce}(\mathrm{mg} / \mathrm{kg})$ in the fine earth and nodules of alluvial soils in the Cis-Ural region, coefficients of metal accumulation in the nodules $\left(\mathrm{C}_{\mathrm{ac}}\right)$, and the Ce-to-La ratios (Savichev, Vodyanitskii, 2009).

The La content in the fine earth varies from 28 to $41 \mathrm{mg} / \mathrm{kg}$. In the nodules, it varies from 14 to $108 \mathrm{mg} / \mathrm{kg}$, and the coefficient of La accumulation in the nodules varies from 0.3 to 3.5 . In the gleyed alluvial agrozem studied on the floodplain of the Mulyanka River polluted by wastewaters, including those from the petroleum refinery, the content of La in the fine earth remains practically stable $(30-34 \mathrm{mg} / \mathrm{kg})$. Its content in the nodules changes from $86 \mathrm{mg} / \mathrm{kg}$ in the deepest C5g horizon to $108 \mathrm{mg} / \mathrm{kg}$ in the C3 horizon at a depth of 75-107 cm. The technogenic lanthanum migrates to a considerable depth in this coarse-textured soil.

The Ce content in fine earth varies from 38 to $60 \mathrm{mg} / \mathrm{kg}$. In the nodules, it varies from 16 to $324 \mathrm{mg} / \mathrm{kg}$. The corresponding coefficients of Ce accumulation in the nodules vary 
from 0.3 to 6.9. In the gleyed alluvial agrozem on the floodplain of the Mulyanka River, the Ce content in the fine earth remains almost stable throughout the soil profile (45-48 $\mathrm{mg} / \mathrm{kg}$ ). In the nodules, it changes from $150 \mathrm{mg} / \mathrm{kg}$ in the deepest $\mathrm{C} 5 \mathrm{~g}$ horizon to 324 $\mathrm{mg} / \mathrm{kg}$ in the C2 horizon at a depth of $49-75 \mathrm{~cm}$. Being most active among lanthanides, the technogenic Ce migrates down the soil profile to a relatively shallow depth and is fixed in the nodules. This is also confirmed by other data. Thus, in the tropical laterites of Cameron, lanthanides are removed from the top iron-enriched horizons and are accumulated in the deeper layers. Cerium is deposited just below the eluvial horizon, and other lanthanides are accumulated in the deeper horizons (Braun, Viers et al., 2005). Similar differentiation of lanthanides is seen in the soil profiles on granodiorites in the New Southern Wales (Australia).

It should be noted that the contents of $\mathrm{La}$ and $\mathrm{Ce}$ in the studied soils of Perm region remain below the clarke values for the pedosphere despite the soil pollution (Taunton, Welch et al., 2000).

Different mechanisms of the formation of rhyzoconcretions and iron nodules are responsible for the difference in the accumulation coefficients of the three elements. Rhyzoconcretions formed with participation of organic root exudates on the floodplain of the unpolluted Obva River are characterized by the weak Ba accumulation $\left(\mathrm{C}_{\mathrm{ac}}=1.2-1.3\right)$ and the depletion of $\mathrm{La}$ and $\mathrm{Ce}\left(\mathrm{C}_{\mathrm{ac}}=0.3-0.7\right)$. Organic ligands in the rhyzoconcretions are mainly spent for iron fixation. This is reflected in the wide Fe-to-Mn ratio in them (25-100). Iron-manganic nodules are formed under conditions of alternating redox regime and are enriched in all the three elements. They are characterized by a more even accumulation of elements and a lower Fe-to-Mn ratio (1.4-12).

The degree of pollution of the river is also important. In the floodplain soil of the strongly polluted Mulyanka River, the accumulation coefficient of Ba in concretions varies from 1.3 to 6.0, the accumulation coefficient of La reaches 2.9-3.5, and the accumulation coefficient of $\mathrm{Ce}$ is as high as 3.1-6.9. Polluted waters of the Mulyanka River enter the deep Kama River and are diluted. As a result, nodules in the soils on the Kama River floodplain have lower concentrations of the studied elements; the coefficients of their accumulation are equal to 1.6 for $\mathrm{Ba}, 1.5$ for $\mathrm{La}$, and 3.3 for Ce.

According to the average coefficients of element accumulation in the concretions, the studied elements form the following sequence: $\mathrm{Ce}(3.7)>\mathrm{Ba}(3.0)>\mathrm{La}(2.2)$. The degree of an element accumulation in the concretion depends on its sensitivity to changes in the redox regime, sorption capacity, and the capacity of the element to form stable complexes with organic ligands. The most pronounced accumulation of Ce in the concretions is explained by its sensitivity for changes in the redox regime. Intermediate position of barium is explained by the precipitation of barite crystals on the active matrix of the concretions; $\mathrm{Ba}$ is a manganophilic element. A relatively low accumulation of $\mathrm{La}$ in the concretions is explained by its physicochemical inactivity.

Let us compare the Ce-to-La ratios in the fine earth and concretions. In the fine earth, this ratio is practically constant and averages to 1.5 , which is close to the clarke value (1.9). In the concretions, it varies from 1.1 to 3.4 and averages to 2.3. A wider Ce-to-La ratio in the concretions signifies that $\mathrm{Ce}$ accumulation in them is more active as compared with La. 


\subsubsection{The soils contaminated with the emissions from the Noril'sk metallurgical enterprise}

Noril'sk is the center of the industrial region in the south of the Taimyr Peninsula. Three metallurgical plants are located in the immediate vicinity of the town producing a high technogenic load and a high level of soil contamination. In the town, the lawn soils are formed by mixing metallurgical and coal slags with soil or peat. Lawns are situated above the heating mains laid at the surface. The gas and dust emissions of the metallurgical enterprise affect the soils outside the town.

The soils were sampled in June of 2004. We analyzed the contaminated soils of Noril'sk and its suburbs located at a different distance from the town to the northeast. Mixed samples of the surface soil horizon $(0-5 \mathrm{~cm})$ were taken, as well as samples from the genetic horizons of the gley cryozem profile formed on heavy and medium marine loams. The soils develop under the conditions of permafrost occurring close to the surface, which results in the weak evaporation of moisture and the development of gley.

The investigated region is subdivided into two zones according to their contamination, i.e., (1) the urban territory, where the soil contamination is controlled by the slags to a great extent; (2) the suburb area at a distance of $4-15 \mathrm{~km}$, where the soil contamination is controlled by aerosols. The soils in Noril'sk are maximally contaminated. The clarkes of the $\mathrm{Cu}, \mathrm{Ni}, \mathrm{Cr}, \mathrm{Zn}$, $\mathrm{Fe}$, and $\mathrm{S}$ are exceeded by $287,78,4.7,3.8,4.1$, and 3.5 times, respectively. In the suburbs, the main pollutants remain the same; however, the pollution's degree is lower; the clarke excess is equal to 65 for $\mathrm{Cu}, 35$ for $\mathrm{Ni}$, and 2.4 for $\mathrm{Fe}$. The town and its suburbs form a technogenic copper-nickel anomaly. The contamination decreases unevenly. As compared to the town, the nickel's contamination decrease is less pronounced in the suburbs than the copper contamination. The slags in the town apparently contain more copper than nickel.

The average content of lanthanides is far below their clarke values in the suburban soils: clarkes of concentration for $\mathrm{La}$ and Ce being equal to 0.4 . The territory in the town's vicinity represents a negative technogenic geochemical anomaly according the content of these metals (Table 10).

\begin{tabular}{|c|c|c|c|c|c|}
\hline $\begin{array}{c}\text { Distance from } \\
\text { Noril'sk, km }\end{array}$ & Horizon & Depth, cm & Y & La & Ce \\
\hline \multicolumn{6}{|c|}{ Noril'sk city } \\
\hline 0 & A & $0-10$ & $34-23$ & $21-15$ & $30-19$ \\
\hline \multicolumn{7}{|c|}{ Noril'sk suburb } \\
\hline \multirow{2}{*}{4} & B & $3-70$ & 24 & 17 & 28 \\
\cline { 2 - 6 } & G & $70-90$ & 33 & 19 & 29 \\
\hline 6 & Mixed & $0-10$ & 18 & 9 & 13 \\
\hline 8 & Mixed & $0-10$ & 30 & 14 & 19 \\
\hline 9 & Mixed & $0-10$ & 19 & 13 & 17 \\
\hline 10 & A & $2-4$ & 16 & 10 & 15 \\
\cline { 2 - 6 } & B1 & $4-45$ & 34 & 19 & 34 \\
\hline 12 & Mixed & $0-10$ & 18 & 15 & 22 \\
\hline 14 & Mixed & $0-10$ & 25 & 13 & 20 \\
\hline 15 & Mixed & $0-10$ & 16 & 12 & 19 \\
\hline Clarke & & & 40 & 34 & 49 \\
\hline
\end{tabular}

Table 10. Content of lanthanides $(\mathrm{mg} / \mathrm{kg})$ in the soils of the Noril'sk technogeochemical anomaly. 
We may judge about the bearing phases of the pollutants from Table 11, which manifests the correlation coefficients between the content of the heavy metals and the iron and sulfur. Chromium and zinc operate as siderophilic elements in the urban soils, which is explained by the soil's contamination with slags containing magnetite. The high magnetic susceptibility of the soils $\left(840 \times 10^{-8} \mathrm{~m}^{3} / \mathrm{kg}\right)$ points to the presence of magnetite. The content of the principal pollutants (nickel and copper) correlates with that of sulfur proving the sulfidic nature of the technogenic $\mathrm{Ni}$ and $\mathrm{Cu}$. It is no surprise because the copper-nickel deposits in Noril'sk and Talnakh are of the sulfide type (Ivanov, 1997).

\begin{tabular}{|c|c|c|c|}
\hline Correlation & Y & La & Ce \\
\hline \multicolumn{4}{|c|}{ Noril'sk city } \\
\hline Fe - Ln & -0.27 & -0.06 & -0.43 \\
\hline S - Ln & -0.63 & -0.22 & -0.73 \\
\hline \multicolumn{4}{|c|}{ Noril'sk suburb } \\
\hline Fe - Ln & $0.76^{*}$ & $0.82^{*}$ & $0.87^{*}$ \\
\hline S - Ln & $-0.67^{*}$ & $-0.66^{*}$ & $-0.65^{*}$ \\
\hline
\end{tabular}

*Reliable at $P=0.95$.

Table 11. Correlation coefficients between the content of sulfur and iron and the content of lanthanides (Ln) in the soils of Noril'sk $(n=14)$ and its suburbs $(n=10)$

The situation is more difficult for the suburban soils. Two opposite processes are effective there: the siderophilic properties are intensified for some elements, and the chalcophilic properties for others. Lanthanides manifest siderophilic properties. This phenomenon is controlled by the increasing influence of the background conditions, under which the content of lanthanides depends on the iron (hydr)oxides. The comparison of the correlation coefficients between lanthanides and Fe in the town (where they are negative) and in the suburbs (where they are positive and high) leads us to the conclusion that the lanthanides enter the soil from the slags rather than from natural bodies in the town. We may speak about the technogenic origin of the lanthanides, although this conclusion cannot be drawn from other more rough indices.

\section{Conclusion}

1. X-ray fluorescence method is the simplest and cost-effective method for studying heavy metals in soils. However, under normal working conditions, niobium with $Z=41$ is the last element that may be identified by this method. The use of $\mathrm{X}$-ray radiometric method makes it possible to determine more elements. In this method, a sample is excited not by emission of the X-ray tube, but by the radioisotope source with a great radiant energy. We have developed the methods for determining $\mathrm{Ba}, \mathrm{La}$, and $\mathrm{Ce}$ contents with the use of ${ }^{241} \mathrm{Am}$ isotope source. The new method has made it possible to obtain data on geochemistry of $\mathrm{Ba}, \mathrm{La}$ and $\mathrm{Ce}$ in soils of humid landscapes.

2. We developed a procedure for the identification of $\mathrm{Pr}, \mathrm{Nd}$ and $\mathrm{Sm}$ using a ${ }^{241} \mathrm{Am}$ isotope source. The procedure is based on the exclusion of the disturbing effect of $\mathrm{Ba}$ and $\mathrm{La}$ on the lines of Pr and $\mathrm{Nd}$, as well as the effect of $\mathrm{La}$ and Ce on the lines of Sm. On the basis of the new method, data were obtained on the geochemistry of three lanthanides in the northern taiga soils. 
3. The classic definition of podzolization as a process of iron and aluminum oxides destruction and removal of the decay products should be supplemented by the phenomena of leaching of a number of heavy metals. In addition to $\mathrm{Fe}$ and $\mathrm{Al}$, many heavy metals manifest well pronounced eluvial-illuvial redistribution in podzolic soils $(\mathrm{Mn}, \mathrm{Cr}, \mathrm{Zn}, \mathrm{Cu}, \mathrm{Ni}, \mathrm{Ce}, \mathrm{La}$ and $\mathrm{Y}$ ). The dimensions of these heavy metals' redistribution exceed that of $\mathrm{Al}$. The inactive participation of $\mathrm{Al}$ in the redistribution is explained by the insignificant share of its reactive fraction. Although the soils of the podzolic group are depleted in the rare earth metals, the latter readily respond to soil podzolization. In a sandy podzol, the degree of leaching of such heavy metals as $\mathrm{Mn}, \mathrm{Cr}, \mathrm{Zn}, \mathrm{Ni}$ and $\mathrm{Zr}$ is markedly higher than in loamy podzolic soil. The leaching of heavy metals from the podzolic horizons has a diagnostic significance, whereas the depletion of metals participating in plant nutrition and biota development is of ecological importance.

Leaching of heavy metals is most closely related to the destruction of clay particles (in heavytextured podzolic soils in particular); the soil's acidity's influence is less noticeable.

The heavy alkalineearth metals ( $\mathrm{Sr}$ and $\mathrm{Ba}$ ) do not participate in podzolization.

4. In the cryozems of the Kolyma Lowland, the high content of La and Ce has been determined. Weathering processes in these cold soils are retarded, which is confirmed by the low role of iron oxidogenesis. This results in preservation of lanthanides and barium in the cryozems.

5. In the Khibiny-Lovozero province of the Kola Peninsula, the area is divided into two parts. In the soils near Lake Umbozero, the contents of $\mathrm{Pr}$ and $\mathrm{Nd}$ are lower than their clarkes, and the content of Sm is below the detection limit. In the background area, the lanthanides are strongly leached from the podzolic soils with $\mathrm{Nd}$ being leached more strongly than Pr.

In the region of the geochemical anomaly (near Lake Lovozero), the contents of $\mathrm{Pr}, \mathrm{Nd}$, and Sm are significantly higher than their clarkes due to the effect of the adjacent deposit of loparites. In the background area, $\mathrm{Y}$ is related to $\mathrm{La}$ and $\mathrm{Ce}$, and $\mathrm{La}$ is related to Ce with high reliability, while the content of Pr is not related to any lanthanide. This is explained by the uniform profile distribution of $\mathrm{Nd}$, in distinction from the eluvial distributions of $\mathrm{Y}, \mathrm{La}$ and $\mathrm{Ce}$.

Positive rare earth anomalies can be expected in soils located not far from the deposits of apatitenephelines, loparites and phosphorites and in the soils developed on alkaline granites and carbonate weathering crusts.

6. In the soddy-podzolic soils and urbanozems of Perm, the variability in the contents of $\mathrm{Ba}, \mathrm{La}$, and $\mathrm{Ce}$ is considerably lower than that of $\mathrm{Ni}$ and $\mathrm{Pb}$. The first three elements are characterized by a smaller portion of technogenic elements as compared with $\mathrm{Ni}$ and $\mathrm{Pb}$. The mean contents of $\mathrm{Ba}, \mathrm{La}$, and $\mathrm{Ce}$ are low despite the possible contribution of technogenic sources. Soil weathering accompanied by the removal of these elements under conditions of humid climate, which is responsible for their low content in the soil profiles.

7. In the alluvial soils of Perm, $\mathrm{Ba}$ is fixed in rhyzoconcretions as barite $\left(\mathrm{BaSO}_{4}\right)$ of, probably, technogenic nature. In the gleyed alluvial agrozem on the Mulyanka River 
floodplain, Ba migrates intensively in the soil profile and is fixed in iron-manganic nodules. The contents of La and Ce in the fine earth of polluted soils remain practically stable, and lanthanides are accumulated in the concretions: the accumulation coefficient reaches 3.5 for $\mathrm{La}$ and 6.9 for Ce.

8. The soil cover in the area influenced by the Noril'sk metallurgical enterprise may be subdivided in terms of the soil contamination into two territories: Noril'sk proper and its suburb at a distance of $4-15 \mathrm{~km}$. The urban soils are maximally polluted with their clarke excesses being equal to 287, 78, 4.7, 4.1, and 3.5 for copper, nickel, chromium, iron, and sulfur, respectively. In the Noril'sk suburbs, the principal pollutants are the same; however, the clarke excess is lower: 65 for $\mathrm{Cu}, 35$ for $\mathrm{Ni}$, and 2.4 for Fe. The urban and suburban territory represents a technogenic copper-nickel-chromium anomaly. By the content of a number of superheavy metals (Ba, La and $\mathrm{Ce}$ ), the territory near the town forms a negative geochemical anomaly. The situation is different in the suburban soils. The rare earth elements $(\mathrm{Y}, \mathrm{La}$ and $\mathrm{Ce})$ have pronounce siderophilic properties due to the natural factors' influence.

\section{References}

Arnautov N.S. (ed.) (1987). Standard Samples of the Chemical Composition of Natural Mineral Substances. Methodological Guidelines, Novosibirsk. [in Russian].

Berenshtein L.E., Masolovich N.S., Sochevanov V.G. \& Ostroumov G.V. (1979). Metrological Basis of Quality Control of Analytical Works, In: Methodological Basis of Studying the Chemical Composition of Rocks, Ores and Minerals, pp. 23-118, Nedra, Moscow. [in Russian].

Bowen H.J.M. (1979). Environmental Chemistry of Elements, Academic, New York.

Braun J.J., Viers J. \& Dupre B. (2005). Solid/Liquid REE Fractionation in the Lateritic System of Goyoum, East Cameroon: The Implication For the Present Dynamics of Soil Covers of the Humid Tropical Regions. Ceochim. Cosmochim. Acta, Vol. 62, pp. 273-299.

Bronnikova M.A. \& Targul'yan V.O. (2005). The Cutan Assemblage in Texture-Differentiated Soils, Akademkniga, Moscow. [in Russian].

Dyatlova N.M., Temkina V.Ya. \& K. I. Popov K.I. (1988). Complexones and Complexonates of Metals, Khimiya, Moscow. [in Russian].

Eremchenko O.Z. \& Moskvina N.V. (2005). The Properties of Soils and Technogenic Surface Formations in the Multistory Districts of Perm City. Pochvovedenie, No. 7, pp. 782789. [Eur. Soil Sci. 38 (7) (2005)], ISSN 1064-2293.

Evans C.H. (1990). Biochemistry of the Lanthanides, Plenum, New York.

Goryachkin S.V. \& Pfeifer E.M. (ed.) (2005). Soils and Perennial Underground Ice of Glaciated and Karst Landscapes in Northern European Russia, Inst. Geogr., Moscow.

Greenwood N.N. \& Earnshaw A. (1997). Chemistry of Elements, 2nd ed., Elsevier.

Inisheva L.I \& Ezupenok E.E. (2007). Contents of Chemical Elements in Highmoor Peats, In: Current Problems of Soil Pollution: II International Scientific Conference, Moscow, Russia (Moscow, 2007), Vol. 2, pp. 63-67. [in Russian].

Ivanov I.N. \& Burmistenko Yu.N. (1986). Neutron-activation Analysis and the Use of Short Living Radionuclide, Energoizdat, Moscow. [in Russian].

Ivanov V.V. (1997). Ecological Geochemistry of Elements, Ekologiya, Moscow. [in Russian], ISBN 5-247-03178-4.

Kabata-Pendias A. \& Pendias H. (1985). Trace Elements in Soils and Plants, CRC, Boca Raton. 
Kashulina G.M., Chekushin V.A. \& Bogatyrev I.V. (2007). Physical Degradation and Chemical Contamination of Soils in Northwestern Europe, In: Current Problems of Soil Pollution: II International Scientific Conference, Moscow, Russia (Moscow, 2007), Vol. 2, pp. 74- 78. [in Russian].

Kaurichev I.S. (ed.) (1989). Soil Science, Agropromizdat, Moscow. [in Russian].

Khitrov V.G. (1985). The Results of Attestation of the System of Standards of the Chemical Composition of Magmatic Rocks. Izv. Akad. Nauk SSSR, Ser. Geol., No. 11, pp. 37-52.

Nikonov V.V., Lukina N.V. \& Frontas'eva M.V. (1999). Trace Elements in Al-Fe-Humus Podzolic Soils Subjected to Aerial Pollution from the Copper-Nickel Production Industry in Conditions of Varying Lithogenic Background. Pochvovedenie, No. 3, pp. 370-382. [Eur. Soil Sci. 32 (3), 338-349 (1999)], ISSN 1064-2293.

Perel'man A.I. (1975). Geochemistry of Landscape, Vysshaya shkola, Moscow. [in Russian].

Perelomov L.V. (2007). Interactions of Rare Earth Elements with Biotic and Abiotic Soil Components. Agrokhimiya, No. 11, pp. 85-96, ISSN 0002-1881.

Savichev A.T. \& Fogel'son M.S. (1987). X-ray Fluorescent Analysis of Silicate Rocks on a Spectrometer. Izv. Akad. Nauk SSSR, Ser. Geol., No. 8, pp. 103-108.

Savichev A.T. \& Sorokin S.E. (2000). X-Ray Fluorescence Analysis of Microelements and Heavy Metals in Soils. Agrokhimiya, No. 12, pp. 71-74, ISSN 0002-1881.

Savichev A.T. \& Vodyanitskii Yu.N. (2009). Determination of Barium, Lanthanum, and Cerium Contents in Soils by the X-Ray Radiometric Method. Eur. Soil Sci., Vol. 42, No 13, pp. 1461-1469, ISSN 1064-2293.

Taunton A.E., Welch S.A. \& Banfield J.F. (2000). Microbial Control on Phosphate and Lanthanide Distributions during Granite Weathering and Soil Formation. Chem. Geol., Vol. 169, pp. 371-382.

Tyler G. (2004a). Rare Earth Elements in Soil and Plant Systems: A Review. Plant Soil, Vol. 267, pp. 191-206, ISSN 0032-079X.

Tyler G. (2004b). Vertical Distribution of Major, Minor, and Rare Elements in Haplic Podzol. Geoderma, Vol. 119, pp. 277-290, ISSN 0016-7061.

Vodyanitskii Yu.N., Mergelov N.S. \& Goryachkin S.V. (2008). Diagnostics of Gleyzation upon a Low Content of Iron Oxides (Using the Example of Tundra Soils in the Kolyma Lowland). Pochvovedenie, No. 3, pp. 261-279. [Eur. Soil Sci. 41 (3), 231-248], ISSN 1064-2293.

Vodyanitskii Yu.N., Vasil'ev A.A. \& Kozheva A.V. (2007). Influence of Iron-Containing Pigments on the Color of Soils on Alluvium of the Middle Kama Plain. Pochvovedenie, No. 3, pp. 318-330. [Eur. Soil Sci. 40 (3), 289-301], ISSN 1064-2293.

Wu Z.M. \& Guo B.S. (1995). Bioinorganic Chemistry of Rare Earth Elements, J. Z. Ni (ed.), Science Press, Beijing, pp. 13-55.

Zhu W.F., Xu S. \& Zhang H. (1995). Biological Effect of Rare Earth Elements in Rare Earth Mineral Zone in the South of China. Chin Sci. Bull., pp. 914-916. 


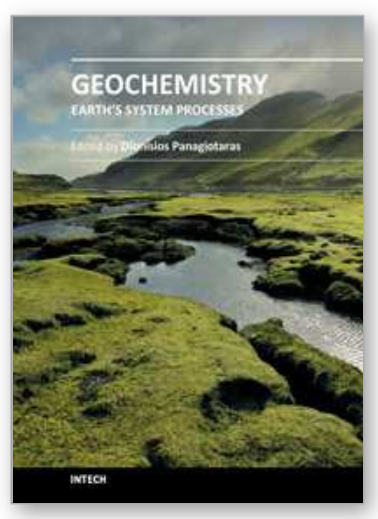

\author{
Geochemistry - Earth's System Processes \\ Edited by Dr. Dionisios Panagiotaras
}

ISBN 978-953-51-0586-2

Hard cover, 500 pages

Publisher InTech

Published online 02, May, 2012

Published in print edition May, 2012

This book brings together the knowledge from a variety of topics within the field of geochemistry. The audience for this book consists of a multitude of scientists such as physicists, geologists, technologists, petroleum engineers, volcanologists, geochemists and government agencies. The topics represented facilitate as establishing a starting point for new ideas and further contributions. An effective management of geological and environmental issues requires the understanding of recent research in minerals, soil, ores, rocks, water, sediments. The use of geostatistical and geochemical methods relies heavily on the extraction of this book. The research presented was carried out by experts and is therefore highly recommended to scientists, underand post-graduate students who want to gain knowledge about the recent developments in geochemistry and benefit from an enhanced understanding of the dynamics of the earth's system processes.

\title{
How to reference
}

In order to correctly reference this scholarly work, feel free to copy and paste the following:

Yu. N. Vodyanitskii and A. T. Savichev (2012). Lanthanides in Soils: X-Ray Determination, Spread in Background and Contaminated Soils in Russia, Geochemistry - Earth's System Processes, Dr. Dionisios Panagiotaras (Ed.), ISBN: 978-953-51-0586-2, InTech, Available from: http://www.intechopen.com/books/geochemistry-earth-s-system-processes/lantanides-in-soils-x-raydetermination-spread-in-background-and-contaminated-soils-in-russia

\section{INTECH}

open science | open minds

\section{InTech Europe}

University Campus STeP Ri

Slavka Krautzeka 83/A

51000 Rijeka, Croatia

Phone: +385 (51) 770447

Fax: +385 (51) 686166

www.intechopen.com

\section{InTech China}

Unit 405, Office Block, Hotel Equatorial Shanghai

No.65, Yan An Road (West), Shanghai, 200040, China

中国上海市延安西路65号上海国际贵都大饭店办公楼 405 单元

Phone: +86-21-62489820

Fax: $+86-21-62489821$ 
(C) 2012 The Author(s). Licensee IntechOpen. This is an open access article distributed under the terms of the Creative Commons Attribution 3.0 License, which permits unrestricted use, distribution, and reproduction in any medium, provided the original work is properly cited. 